\title{
Evaluation of Probiotic Potential of Some Native Lactobacillus Strains on the Growth Performance and Serum Biochemical Parameters of Japanese Quails (Coturnix Coturnix Japonica) during Rearing Period
}

-Author(s)
Siadati SA'
Ebrahimnezhad $Y^{\prime}$
Salehi Jouzani Gh"
Shayegh J"I
I Department of Animal Science, Shabestar
Branch, Islamic Azad University, Shabestar,
Iran
" Microbial Biotechnology Department, Agri-
cultural Biotechnology Research Institute of
Iran (ABRII), Agricultural Research, Educa-
tion and Extension Organization (AREEO),
Karaj, Iran
III Veterinary Medicine College, Shabestar
Branch, Islamic Azad University, Iran

\section{Mail Address}

Corresponding author e-mail address Yahya Ebrahimnezhad

Department of Animal Science, Shabestar Branch, Islamic Azad University, Shabestar,

East Azarbaijan, Iran.

Tel: $\quad$ (+98) 42425311

Email: ebrahimnezhad@iaushab.ac.ir

\section{- Keywords}

Growth performance, Japanese quails, native lactobacilli, serum biochemical parameters.

\section{ABSTRACT}

The objective of the present study was to evaluate the probiotic effects of different concentrations of four selected native Lactobacillus strains on the growth performance and serum biochemical parameters of Japanese quails. A completely randomized design (CRD) was applied, including seven probiotic treatments with four replicates of 20 quails each, totaling 560 quails. Treatments were applied for five weeks. Four native Lactobacillus strains were anaerobically grown in a 10-L batch fermenter and lyophilized $\left(10^{10} \mathrm{CFU} / \mathrm{g}\right)$. Treatments were as follows: T1: control (basal diet); T2: commercial probiotic CP1; T3: commercial probiotic $\mathrm{CP} 2$; and $\mathrm{T} 4, \mathrm{~T} 5, \mathrm{~T} 6$, and T7: four native strains added at levels of 50, 100, 150, and $200 \mathrm{~g} /$ ton diet, respectively. The native probiotics significantly improved body weight gain (BWG) and feed conversion ratio ( $F C R$ ) during the starter, finisher, and overall periods (35 days) $(p<0.05)$, whereas no significant effect was observed on feed intake. The native strains significantly influenced the serum glucose, total protein, globulin, phosphorus, uric acid, low-density lipoprotein (LDL), LDL/HDL ratio, white blood cell counts (WBC), and mean corpuscular hemoglobin concentration $(\mathrm{MCHC})$ of quails during the rearing period $(p<0.05)$, whereas treatments had no influence $(p>0.05)$ on blood cholesterol, calcium, high-density lipoprotein (HDL), or hemoglobin (HB) levels or on red blood cell counts (RBC). The cecal and small intestine samples of the quails fed the native Lactobacillus strains contained significantly higher Lactobacillus spp. and lower E. coli populations compared with the control diet and those supplemented with commercial probiotics. It was concluded that the use of the native Lactobacillus strains (150 g/ ton diet) promoted the best performance of Japanese quails.

\section{INTRODUCTION}

The term probiotic is etymologically derived from the Latin preposition pro ("for" or "in support of") and the Greek word (biotic), which literally means "for life". In 1989, Fuller defined probiotics as live microbial food supplements that beneficially affect the host animal by improving the intestinal microbial balance (Fuller, 1989). There is a huge body of evidence that support the significant positive impacts of probiotics and bioactive compounds on poultry performance and health. Probiotic bacteria improve the economic indexes and resistance to pathogens of laying or meat-type chickens (Hippenstiel et al., 2011; Aazami et al., 2014; Cean et al., 2015; Mountzouris et al., 2007). Lactobacilli and Enterococci have been widely used as probiotics in the poultry industry (Kabir et al., 2004; Awad et al., 2009; Aazami et al., 2014; Mountzouris et al., 2007). The main postulated health benefits associated with probiotics include improving the gut microflora balance, stimulating the immune reaction, producing different antimicrobial substances, 
Siadati SA, Ebrahimnezhad Y, Salehi Jouzani G, Shayegh J
Evaluation of Probiotic Potential of Some Native Lactobacillus Strains on the Growth Performance and Serum Biochemical Parameters of Japanese Quails (Coturnix Coturnix Japonica) during Rearing Period

Holbrook, NY, USA) for subsequent experiments (Vandeplas et al., 2009).

\section{Birds and experimental treatments}

All the experiment procedures were approved by the Animal Care and Ethics Committee of the Tarbiat Modares University and complied with the Guidelines for the Care and Use of Animals in Research.

In total, 560 one-day-old Japanese quails of both sexes (equally divided) were distributed according to a completely randomized design into seven treatments with four replicates of 20 quails each. The experiment lasted five weeks. The day-old chicks were purchased from a commercial hatchery. Birds in each replicate was allocated to a floor pen $\left(40 \times 40 \mathrm{~cm}^{2}\right)$. Room temperature was maintained at $32^{\circ} \mathrm{C}$ during the first week and gradually decreased by $3^{\circ} \mathrm{C}$ weekly until $22^{\circ} \mathrm{C}$, and then maintained constant until the end of the experiment (Khaksar et al., 2012). The quails were subjected to continuous lighting program of 23L:1D during the entire experiment (Kermanshahi et al., 2015).

Two commercial probiotics Perimalac ${ }^{\circledR}\left(1 \times 10^{8}\right.$ cfu/g) (commercial product 1, CP1) and Protexin ${ }^{\circledR}$ $\left(2 \times 10^{9} \mathrm{cfu} / \mathrm{g}\right)$ (commercial product 2, CP2) were used as positive controls. Protexin (International Ltd, Somerest, UK) is a multistrain probiotic consisting of seven bacterial and two yeast strains: Lactobacillus plantarum, Lactobacillus bulgaricus, Lactobacillus acidophilus, Lactobacillus rhamnosus, Bifidobacterium bifidum, Streptococcus thermophilus, Enterococcus faecium Aspergillus oryzae and Candida pintolopesii. The commercial probiotic Primalac (Star Labs Inc., Clarksdale, MO, USA) is a multistrain probiotic including four bacterial strains: Lactobacillus casei, Lactobacillus acidophilus, Bifidobacterium thermophilum, and Enterococcus faecium. The native strains were used at 50, 100, 150 and $200 \mathrm{~g} /$ ton diet. The native strains consist of (Lactobacillus crispatus), ES7 (Lactobacillus salivarius), OR10 (Lactobacillus crispatus), and M4 (Lactobacillus oris) at $10^{10}-10^{11} \mathrm{CFU} / \mathrm{g}$.

The following treatments were applied: $\mathrm{T} 1$ : basal diet (control diet without probiotics), T2: basal diet + CP1 (908 g/ton in the starter diet and $454 \mathrm{~g} /$ ton in the finisher diet), T3: basal diet + CP2 (150 g/ton in the starter diet and $100 \mathrm{~g} /$ ton in finisher phase), T4: basal diet $+50 \mathrm{~g}$ of the native strains/ton, T5: basal diet + $100 \mathrm{~g}$ of the native strains/ton, T6: basal diet $+150 \mathrm{~g}$ of the native strains/ton, and T7: basal diet $+200 \mathrm{~g}$ of the native strains/ton. The diets were supplied as mash, and formulated for the starter ( 1 to $21 \mathrm{~d}$ ) and 
Siadati SA, Ebrahimnezhad Y, Salehi Jouzani G, Shayegh J
Evaluation of Probiotic Potential of Some Native Lactobacillus Strains on the Growth Performance and Serum Biochemical Parameters of Japanese Quails (Coturnix Coturnix Japonica) during Rearing Period

ventral cutting of the neck. As both male and female Japanese quails were reared together, their blood samples were pooled before the biochemical and hematological analyses, which allows reducing the cost and increasing the level of automation of the analyses. Samples of approximately $1 \mathrm{~mL}$ of whole blood were collected from eight quails per treatment by jugular vein puncture after sacrifice. Serum globulin, total protein, glucose, high-density lipoprotein (HDL), lowdensity lipoprotein (LDL), cholesterol, LDL/HDL ratio, uric acid, phosphorus, and calcium contents were analyzed using an automatic biochemical analyzer (DiaSys, Diagnostic Systems, Germany), following the instructions of the corresponding reagent kits (Pars Azmon Co., Tehran, Iran). Blood (approximately $2 \mathrm{~mL}$ ) was collected from the same birds and placed into tubes containing EDTA- $\mathrm{Na}_{2}$ (an anticoagulant) for subsequent determination of the mean corpuscular hemoglobin concentration $(\mathrm{MCHC})$, hemoglobin $(\mathrm{HB})$ level, and white blood cell (WBC) and red blood cell (RBC) counts using an automated hematology analyzer (Celltac E, MEK-7222 J/K; Nihon Kohden Co., Tokyo, Japan) within $2 \mathrm{~h}$ after collection.

\section{Evaluation of the cecal and small intestine Lactobacilli and E. coli populations}

At the end of the experiment, four birds per treatment were randomly selected and sacrificed by decapitation. The cecal and small intestine contents of each bird were transferred to a sterile glass vial for microbial enumeration. Cecal and small intestine digesta samples $(1 \mathrm{~g})$ were diluted at 1:10 with normal saline solution, which were then further diluted to $10^{-3}, 10^{-5}, 10^{-7}$, and $10^{-9}$, in normal saline solution, out of which $100 \mu \mathrm{L}$ were plated on agar plates. In order to evaluate Lactobacillus spp. and E. coli populations, the diluted samples were seeded on MRS agar (Merck, Germany) and MacConkey agar (Merck, Germany), respectively, and incubated for $48 \mathrm{~h}$ at $37^{\circ} \mathrm{C}$. Colony forming units (CFU) were expressed as log 10 CFU per gram of cecal and small intestine content (Hashemi et al., 2012).

\section{Statistical analysis}

Data were analyzed by analysis of variance using the GLM procedure of SAS/STAT software (SAS Institute, 2003) as a completely randomized experimental design with replicates as experimental units. Statistically significant differences among treatments was tested by Duncan's multiple range test at $p \leq 0.05$. 


\section{RESULTS AND DISCUSSION}

\section{Effect of probiotics on growth performance}

The results (Tables 2 and 3) showed that dietary inclusion of probiotics (native strains and commercial products) significantly increased body weight gain (BWG) and improved feed conversion ratio (FCR) during the starter and overall periods $(p<0.05)$ compared with the basal diet (T1). Feed intake was not influenced by the dietary treatments in none of the evaluated periods.
The highest and lowest BWG values were obtained with the native probiotic product at $150 \mathrm{~g} /$ ton (T6, $202.99 \mathrm{~g}$ ) and with the control diet (T1, 176.41 g), respectively, during the overall period (Table 3 ). Interestingly, the BWG during the overall period of the birds fed the diet with native probiotic at $150 \mathrm{~g} /$ ton (T6) was significantly higher than that of those fed CP1 (188.72 g) and CP2 (188.50 g) ( $p<0.05)$. This was also observed for both the starter and finisher periods.

Table 2 - Effects of commercial and native probiotics on the performance of Japanese quails

\begin{tabular}{|c|c|c|c|c|c|c|}
\hline \multirow[b]{2}{*}{ Treatment } & \multicolumn{3}{|c|}{ Starter phase (1 to $21 \mathrm{~d}$ ) } & \multicolumn{3}{|c|}{ Finisher phase (22 to $35 \mathrm{~d}$ ) } \\
\hline & $\mathrm{Fl}(\mathrm{g})$ & BWG (g) & FCR & $\mathrm{Fl}(\mathrm{g})$ & BWG (g) & FCR \\
\hline Control $\left(\mathrm{T}_{1}\right)$ & $252.83 \pm 3.99$ & $104.66^{c} \pm 1.41$ & $2.41^{\mathrm{a}} \pm 0.036$ & $287.55 \pm 7.46$ & $71.75^{c} \pm 1.12$ & $4.01^{\mathrm{a}} \pm 0.084$ \\
\hline $\mathrm{CP} 1\left(\mathrm{~T}_{2}\right)$ & $248.21 \pm 4.53$ & $112.59^{b} \pm 2.99$ & $2.22^{\mathrm{bc}} \pm 0.032$ & $297.42 \pm 6.08$ & $76.12^{\mathrm{bc}} \pm 0.66$ & $3.91^{\mathrm{ab}} \pm 0.097$ \\
\hline $\mathrm{CP} 2\left(\mathrm{~T}_{3}\right)$ & $247.63 \pm 4.96$ & $112.16^{b} \pm 3.53$ & $2.21^{b c} \pm 0.027$ & $301.75 \pm 4.76$ & $76.33^{\mathrm{bc}} \pm 1.91$ & $3.96^{\mathrm{ab}} \pm 0.115$ \\
\hline NP 50g/ton $\left(T_{4}\right)$ & $257.78 \pm 4.19$ & $115.95^{\mathrm{ab}} \pm 1.79$ & $2.20^{b} \pm 0.045$ & $306.33 \pm 3.38$ & $80.00^{\mathrm{ab}} \pm 1.61$ & $3.83^{\mathrm{ab}} \pm 0.110$ \\
\hline NP $100 \mathrm{~g} / \operatorname{ton}\left(T_{5}\right)$ & $249.84 \pm 5.83$ & $114.21^{\mathrm{ab}} \pm 1.21$ & $2.18^{b c} \pm 0.038$ & $294.08 \pm 8.57$ & $76.28^{b c} \pm 1.22$ & $3.85^{\mathrm{ab}} \pm 0.049$ \\
\hline NP $150 \mathrm{~g} /$ ton $\left(T_{6}\right)$ & $255.54 \pm 6.07$ & $120.24^{\mathrm{a}} \pm 2.20$ & $2.12^{\mathrm{bc}} \pm 0.029$ & $291.95 \pm 5.17$ & $82.75^{a} \pm 2.09$ & $3.53^{c} \pm 0.065$ \\
\hline NP $200 \mathrm{~g} / \operatorname{ton}\left(T_{7}\right)$ & $250.42 \pm 3.56$ & $119.13^{\mathrm{ab}} \pm 1.52$ & $2.10^{c} \pm 0.030$ & $293.03 \pm 7.85$ & $78.85^{\mathrm{ab}} \pm 1.56$ & $3.71^{b c} \pm 0.060$ \\
\hline$p$-Value & 0.7113 & 0.0017 & 0.0001 & 0.4636 & 0.0019 & 0.0131 \\
\hline
\end{tabular}

Values are expressed as means \pm standard error of the mean. ${ }^{A-d}$ Values followed by different letters on the same row indicate significant differences $(p<0.05)$.

$\mathrm{Fl}=$ Feed intake, $\mathrm{BWG}=$ Body weight gain, $\mathrm{FCR}=$ Feed conversion ratio, $\mathrm{CP}=$ commercial probiotic, $\mathrm{NP}=$ native probiotic .

Table 3 - Effects of commercial and native probiotics on the performance of Japanese quails

\begin{tabular}{lccc}
\hline & \multicolumn{3}{c}{ Overall (1 to 35d) } \\
\hline Treatment & Fl (g) & BWG $(g)$ & FCR \\
\hline Control $\left(T_{1}\right)$ & $540.39 \pm 9.66$ & $176.41^{\mathrm{c}} \pm 1.20$ & $3.06^{\mathrm{a}} \pm 0.039$ \\
CP1 $\left(\mathrm{T}_{2}\right)$ & $545.64 \pm 9.18$ & $188.72^{\mathrm{b}} \pm 3.39$ & $2.89^{\mathrm{b}} \pm 0.038$ \\
CP2 $\left(\mathrm{T}_{3}\right)$ & $549.45 \pm 8.10$ & $188.50^{\mathrm{b}} \pm 2.26$ & $2.91^{\mathrm{b}} \pm 0.010$ \\
NP 50g/ton $\left(\mathrm{T}_{4}\right)$ & $564.13 \pm 3.96$ & $195.95^{\mathrm{ab}} \pm 2.50$ & $2.88^{\mathrm{b}} \pm 0.048$ \\
NP 100g/ton $\left(\mathrm{T}_{5}\right)$ & $543.94 \pm 12.22$ & $190.50^{\mathrm{b}} \pm 1.95$ & $2.85^{\mathrm{b}} \pm 0.040$ \\
NP 150g/ton $\left(\mathrm{T}_{6}\right)$ & $547.50 \pm 8.94$ & $202.99^{\mathrm{a}} \pm 1.14$ & $2.69^{\mathrm{c}} \pm 0.031$ \\
NP 200g/ton $\left(T_{7}\right)$ & $543.46 \pm 10.92$ & $197.98^{\mathrm{a}} \pm 3.00$ & $2.74^{\mathrm{c}} \pm 0.034$ \\
$p$-Value & 0.6555 & 0.0001 & 0.0001 \\
\hline
\end{tabular}

Values are expressed as means \pm standard error of the mean. ${ }^{A-d}$ Values followed by different letters on the same row indicate significant differences $(p<0.05)$.

$\mathrm{Fl}=$ Feed intake, $\mathrm{BWG}=$ Body weight gain, $\mathrm{FCR}=$ Feed conversion ratio, $\mathrm{CP}=$ commercial probiotic, NP = native probiotic

The FCR of the birds fed the diet with native probiotic at $150 \mathrm{~g} / \mathrm{ton}$ (T6) was significantly lower than that of the T2 (CP1, 2.89), T3 (CP2, 2.91), and control treatments during the overall period, demonstrating the better efficiency of the native strains compared with the commercial products (Table 3). This pattern was also observed in the finisher period $(p<0.05)$. However, in the starter period, the highest and the lowest FCR $(p<0.05)$ were obtained with the control diet and the diet with native probiotic at $200 \mathrm{~g} / \mathrm{ton}$, respectively (Table 2 ).
These results are consistent with those of Pelicano et al. (2004) and Gunal et al. (2006) in broilers, and Cakir et al. (2008) and Babazadeh et al. (2011), who did not find any significant effect of probiotics on feed intake of Japanese quails, whereas Corrêa et al. (2003) and Bitterncourt et al. (2011) showed that dietary probiotics reduced the feed intake of broilers.

Alkhalf et al. (2010) reported that a probiotic level of $0.8 \mathrm{~g} / \mathrm{kg}$ feed enhanced the live performance of broilers compared with the control diet and that with $1.6 \mathrm{~g}$ probiotic/ $\mathrm{kg}$. This indicates that increasing the level of probiotics in the feed does not ensure better performance, which is in accordance with the result of the present study, as T6 $(150 \mathrm{mg} / \mathrm{kg})$ promoted better performance than T7 $(200 \mathrm{mg} / \mathrm{kg})$. Chimote et al. (2009) showed that significantly higher body weight gain and better feed conversion ratio in Japanese quails fed probiotics those fed a control group. Kalavathy et al. (2003) reported that the supplementation of probiotics in broiler diets improved their body weight gain and feed conversion ratio from 1 to 42 days of age. Yu et al. (2007) also showed that the supplementation of an intestinal Lactobacillus reuteri strain to a wheatbased diet increased body weight gain of broilers from 1 to 21 days of age. Moreover, Khaksefidi \& Ghoorchi (2006) reported that the body weight gain and feed conversion ratio of broilers fed probiotics 
were significantly improved compared with those fed control diets. On the other hand, Ramarao et al. (2004) reported that the body weight gain of broilers was not influenced by the dietary supplementation with probiotics, as opposed to findings of this experiment. The results of the present study were contrary with the findings of Ergün et al. (2000) and Arslan (2004), who suggested that probiotic supplementation did not influence the feed efficiency ratio or body weight gain of broilers.

The reason for the improvements in body weight gain and feed conversion ratio of the Japanese quails fed probiotics in the present experiment was probably an increase in the population of beneficial intestinal bacteria and reduction of the population of pathogenic bacteria, and consequently, better nutrient digestibility and absorption. The results of the present experiment confirmed the probiotic potential of the selected strains, and were consistent with those obtained in other studies, showing that the presence of probiotic additives enhances the performance (FCR, BWG and BW) of broilers (Ashayerizadeh et al., 2009; Arslan \& Saatci, 2004; Yalçın et al., 2000; Sharifi et al., 2011; Kasmani et al., 2012; Chimote et al., 2009; Babazadeh et al., 2011; Kheiri et al., 2015).

\section{Effect of probiotic on blood parameters}

The effects of different probiotics on serum biochemical parameters and blood parameters are shown in Tables 4, 5, and 6, respectively. The inclusion of native and commercial probiotics had a significant effect on serum glucose, total protein, globulin, phosphorus, uric acid, LDL and LDL/HDL ratio, WBC, and MCHC of Japanese quails $(p<0.05)$. No differences ( $p>0.05)$ in cholesterol, calcium, HDL, RBC, and HB values were detected (1-35 d). The serum cholesterol results of the present study are in conflict with the findings of Panda et al. (2006), who reported that the probiotic L. sporogenes (100 mg/kg diet) significantly reduced total cholesterol levels in broilers. Dibaji et al. (2012) and Kalavathy et al. (2003) also found that feeding probiotics decreased serum LDL, but not HDL levels in broilers.

In the present experiment, feeding probiotics had no effect on serum calcium levels, in agreement with the findings of Sahin et al. (2008), who did not find any influence of feeding a probiotic on the serum calcium levels of quails. On the other hand, Scholz-Ahrens et al. (2007) explained that probiotics may increase the intestinal absorption of calcium, because the short-

Table 4 - Effects of commercial and native probiotics on selected serum biochemical parameters of Japanese quails

\begin{tabular}{|c|c|c|c|c|c|c|}
\hline \multirow[b]{2}{*}{ Treatment } & \multicolumn{6}{|c|}{ Item } \\
\hline & Glucose (mg/dL) & Cholesterol (mg/dL) & Total protein $(\mathrm{g} / \mathrm{dL})$ & Globulin (g/dL) & Phosphorus (mg/dL) & Calcium (mg/dL) \\
\hline Control $\left(T_{1}\right)$ & $292.25^{\mathrm{a}} \pm 6.33$ & $203.00 \pm 2.73$ & $3.87^{`} \pm 0.22$ & $2.62^{\mathrm{b}} \pm 0.38$ & $5.12^{b} \pm 0.23$ & $9.07 \pm 0.53$ \\
\hline $\mathrm{CP} 1\left(\mathrm{~T}_{2}\right)$ & $276.00^{\mathrm{ab}} \pm 9.32$ & $204.75 \pm 10.30$ & $4.87^{\mathrm{ab}} \pm 0.35$ & $3.62^{\mathrm{ab}} \pm 0.83$ & $6.65^{\mathrm{a}} \pm 0.42$ & $9.10 \pm 0.31$ \\
\hline $\mathrm{CP} 2\left(\mathrm{~T}_{3}\right)$ & $267.25^{b} \pm 6.35$ & $196.00 \pm 9.41$ & $5.02^{\mathrm{ab}} \pm 0.42$ & $3.72^{\mathrm{a}} \pm 0.79$ & $6.35^{\mathrm{ab}} \pm 0.48$ & $9.30 \pm 0.55$ \\
\hline NP $50 \mathrm{~g} / \mathrm{ton}\left(\mathrm{T}_{4}\right)$ & $284.50^{\mathrm{ab}} \pm 7.53$ & $195.00 \pm 3.57$ & $4.0 b^{c} \pm 0.16$ & $2.70^{b} \pm 0.42$ & $5.37^{b} \pm 0.14$ & $9.45 \pm 0.41$ \\
\hline$N P 100 \mathrm{~g} / \operatorname{ton}\left(\mathrm{T}_{5}\right)$ & $281.50^{\mathrm{ab}} \pm 4.99$ & $202.75 \pm 3.81$ & $4.10^{b c} \pm 0.20$ & $2.75^{\mathrm{ab}} \pm 0.45$ & $5.55^{\mathrm{ab}} \pm 0.28$ & $8.97 \pm 0.43$ \\
\hline NP $150 \mathrm{~g} / \operatorname{ton}\left(\mathrm{T}_{6}\right)$ & $262.25^{b} \pm 7.21$ & $194.75 \pm 2.28$ & $5.20^{\mathrm{a}} \pm 0.41$ & $3.75^{\mathrm{a}} \pm 0.81$ & $6.77^{a} \pm 0.50$ & $9.77 \pm 0.26$ \\
\hline NP $200 \mathrm{~g} /$ ton $\left(T_{7}\right)$ & $265.00^{\mathrm{b}} \pm 4.81$ & $200.00 \pm 8.76$ & $4.95^{\mathrm{ab}} \pm 0.25$ & $3.55^{\mathrm{ab}} \pm 0.47$ & $6.12^{\mathrm{ab}} \pm 0.43$ & $9.62 \pm 0.23$ \\
\hline$p$-Value & 0.0417 & 0.8836 & 0.0244 & 0.0410 & 0.0329 & 0.7721 \\
\hline
\end{tabular}

Values are expressed as means \pm standard error of the mean. ${ }^{A-d}$ Values followed by different letters on the same row indicate significant differences $(p<0.05)$. $C P=\operatorname{commercial}$ probiotic, NP = native probiotic

Table 5 - Effects of commercial and native probiotics on selected serum biochemical parameters of Japanese quails

\begin{tabular}{lcccc}
\hline & \multicolumn{3}{c}{ Item } \\
\hline Treatment & Uric acid $(\mathrm{mg} / \mathrm{dL})$ & $\mathrm{HDL}(\mathrm{mg} / \mathrm{dL})$ & $\mathrm{LDL}(\mathrm{mg} / \mathrm{dL})$ & $\mathrm{LDL} / \mathrm{HDL}$ \\
\hline Control $\left(T_{1}\right)$ & $3.92^{\mathrm{a}} \pm 0.08$ & $82.25 \pm 1.60$ & $78.25^{\mathrm{a}} \pm 1.65$ & $0.95^{\mathrm{a}} \pm 0.02$ \\
$C P 1\left(T_{2}\right)$ & $3.00^{\mathrm{b}} \pm 0.24$ & $84.75 \pm 3.63$ & $74.25^{\mathrm{ab}} \pm 6.70$ & $0.87^{\mathrm{ab}} \pm 0.04$ \\
CP2 $\left(T_{3}\right)$ & $3.52^{\mathrm{ab}} \pm 0.16$ & $84.00 \pm 2.67$ & $67.00^{\mathrm{ab}} \pm 5.59$ & $0.80^{\mathrm{ab}} \pm 0.08$ \\
NP 50g/ton $\left(T_{4}\right)$ & $3.37^{\mathrm{ab}} \pm 0.23$ & $85.25 \pm 2.42$ & $62.25^{\mathrm{b}} \pm 4.21$ & $0.73^{\mathrm{b}} \pm 0.06$ \\
NP 100g/ton $\left(T_{5}\right)$ & $3.10^{\mathrm{b}} \pm 0.33$ & $82.00 \pm 1.47$ & $77.25^{\mathrm{a}} \pm 4.33$ & $0.94^{\mathrm{a}} \pm 0.06$ \\
NP 150g/ton $\left(T_{6}\right)$ & $2.85^{\mathrm{b}} \pm 0.10$ & $87.50 \pm 2.90$ & $60.00^{\mathrm{b}} \pm 1.08$ & $0.69^{\mathrm{b}} \pm 0.02$ \\
NP 200g/ton $\left(T_{7}\right)$ & $3.25^{\mathrm{b}} \pm 0.15$ & $86.00 \pm 3.18$ & $69.75^{\mathrm{ab}} \pm 4.59$ & $0.81^{\mathrm{ab}} \pm 0.06$ \\
$p$-Value & 0.0263 & 0.7637 & 0.0475 & 0.0292 \\
\hline
\end{tabular}

A-d Values are Means \pm S.E.M with different letters on the same row implies significant differences $(p<0.05)$.

$\mathrm{HDL}=$ High density lipoprotein, $\mathrm{LDL}=\mathrm{Low}$ density lipoprotein 
Table 6 - Effects of commercial and native probiotics on hematological parameters of Japanese quails

\begin{tabular}{|c|c|c|c|c|}
\hline \multirow[b]{2}{*}{ Treatment } & \multicolumn{4}{|c|}{ Item } \\
\hline & $\begin{array}{c}\text { RBC } \\
\left(\times 10^{6} / \mu \mathrm{L}\right)\end{array}$ & $\begin{array}{c}\text { WBC } \\
\left(\times 10^{3} \mu \mathrm{L}\right)\end{array}$ & $\begin{array}{c}\mathrm{MCHC} \\
(\%)\end{array}$ & $\begin{array}{c}\mathrm{Hb} \\
(\mathrm{g} / \mathrm{dL})\end{array}$ \\
\hline Control $\left(T_{1}\right)$ & $2.74 \pm 0.07$ & $21.50^{b} \pm 1.35$ & $35.79^{b} \pm 0.51$ & $16.65 \pm 1.73$ \\
\hline $\mathrm{CP} 1\left(\mathrm{~T}_{2}\right)$ & $2.78 \pm 0.07$ & $24.12^{\mathrm{ab}} \pm 1.15$ & $36.30^{\mathrm{ab}} \pm 0.33$ & $16.35 \pm 0.68$ \\
\hline $\mathrm{CP} 2\left(\mathrm{~T}_{3}\right)$ & $2.86 \pm 0.11$ & $25.80^{a} \pm 1.50$ & $36.52^{\mathrm{ab}} \pm 0.32$ & $16.80 \pm 1.51$ \\
\hline NP 50g/ton $\left(\mathrm{T}_{4}\right)$ & $2.71 \pm 0.11$ & $25.17^{a} \pm 1.01$ & $37.75^{\mathrm{a}} \pm 0.40$ & $16.47 \pm 0.84$ \\
\hline $\mathrm{NP} 100 \mathrm{~g} / \mathrm{ton}\left(\mathrm{T}_{5}\right)$ & $2.66 \pm 0.15$ & $23.45^{\mathrm{ab}} \pm 0.86$ & $36.07^{b} \pm 0.45$ & $16.17 \pm 0.55$ \\
\hline NP $150 \mathrm{~g} /$ ton $\left(T_{6}\right)$ & $2.81 \pm 0.06$ & $26.30^{a} \pm 1.46$ & $37.92^{\mathrm{a}} \pm 0.60$ & $16.72 \pm 1.28$ \\
\hline NP $200 \mathrm{~g} /$ ton $\left(T_{7}\right)$ & $2.88 \pm 0.16$ & $26.92^{a} \pm 1.27$ & $36.67^{\mathrm{ab}} \pm 0.75$ & $17.02 \pm 1.64$ \\
\hline$p$-Value & 0.8207 & 0.0490 & 0.0477 & 0.9993 \\
\hline
\end{tabular}

Values are expressed as means \pm standard error of the mean. ${ }^{A-d}$ Values followed by different letters on the same row indicate significant differences $(p<0.05)$.

$\mathrm{RBC}=$ red blood cells, $\mathrm{WBC}=$ white blood cells, $\mathrm{MCHC}=$ mean cell hemoglobin concentration, $\mathrm{Hb}=$ hemoglobin, $\mathrm{CP}=$ commercial probiotic, $\mathrm{NP}=$ native probiotic

chain fatty acids produced by some probiotic bacteria reduce gastrointestinal $\mathrm{pH}$, thereby increasing calcium solubility and presumably, calcium absorption.

Significant reductions were recorded in serum glucose values in the probiotic groups (native probiotic at 150 and $200 \mathrm{~g} / \mathrm{ton}$, and (P2) compared with the control group $(p<0.05)$, but no differences between commercial and native probiotics were detected $(p>0.05)$. The reduction of serum glucose levels in quails fed probiotics in the present study are in agreement with the findings of Al-Kassie et al. (2008) and Arslan \& Saatci (2004) in broilers and quails respectively, whereas Abd-El-Rahman et al. (2012) reported that feeding probiotics increased serum glucose levels in broilers. These differences serum glucose levels among studies may be ascribed to dietary ingredients, nutrient composition, and probiotic effectiveness.

The Japanese quails fed native probiotic strains at $150 \mathrm{~g} / \mathrm{ton}$ presented higher serum total protein level compared with those fed the commercial probiotics, which were not statistically different. In addition, the highest blood globulin level was obtained in the treatments containing native probiotic strains $(150 \mathrm{~g} /$ ton) and the commercial probiotic CP2 compared with native probiotic strains ( $50 \mathrm{~g} / \mathrm{ton}$ ) and the control group. The results of the present study are in agreement with the findings of Arslan \& Saatci (2004) who showed that a probiotic-supplemented diet fed to Japanese quails increased serum total protein levels. However, Yalçın et al. (2000), Djouvinov et al. (2005), Sahin et al. (2008), and Alkhalf et al. (2010) did not detect any influence of dietary probiotic supplementation on total protein and globulin levels in the serum of quails, broilers, quails, and ducks, respectively. The higher serum total protein levels detected in the birds fed probiotics, except for those fed the native probiotic strains at $50 \mathrm{~g} / \mathrm{ton}$, compared with those fed the control diet in the present study may be due to the better protein digestion promoted by probiotics (ElFaham et al., 2014).

The highest and lowest phosphorus contents were observed in the quails fed the native probiotic strains at $150 \mathrm{~g} / \mathrm{ton}$ and those of the control group, respectively. Significant increases in serum phosphors values were recorded in the native probiotic strains (100, 150 and $200 \mathrm{~g} /$ ton) and commercial probiotics (CP1 and CP2) compared with the native probiotic strain $50 \mathrm{~g} /$ ton and control group $(p<0.05)$. These findings are comparable with the results of Hosseini et al. (2013), who found higher serum phosphorus levels in broilers fed a probiotic-supplemented diet compared with those fed a control diet. Eizaguirre et al. (2002) reported that probiotics reduced intestinal $\mathrm{pH}$ in humans, improving the absorption of minerals by enhancing their solubility.

Serum uric acid levels were significantly lower in the quails fed the native probiotic at 100, 150 and 200 $\mathrm{g} / \mathrm{ton}$ and the CP1 compared with the control diet, but those fed the diets containing CP2 and the native probiotic at $50 \mathrm{~g} /$ ton presented intermediate levels, not statistically different from the other treatments. ElFaham et al. (2014) also reported lower uric acid levels in broilers fed a probiotic than those fed a control diet, and suggested that probiotics may improve kidney function and protein metabolism, and consequently, increase nitrogen utilization. Moreover, certain probiotic strains utilize urea, uric acid, and creatinine and other toxins as nutrients for growth (Salim et al., 2011). The lower uric acid levels detected in the quails fed probiotics are consistent with the findings of Newaj-Fyzul et al. (2007) and Tonekabon (2013) in rainbow trout. The observed reduction in serum uric acid level with the diets containing probiotics in our experiment may be due to better kidney function and 
protein metabolism and consequently, better nitrogen utilization.

The maximum total protein $(5.20 \mathrm{~g} / \mathrm{dL})$, globulin (3.75 g/dL), phosphorous (6.77 $\mathrm{mg} / \mathrm{dL})$, and MCHC (37.92\%) as well as minimum serum glucose (264 $\mathrm{mg} / \mathrm{dL})$, uric acid $(2.75 \mathrm{mg} / \mathrm{dL}), \mathrm{LDL}(60 \mathrm{mg} / \mathrm{dL})$, and LDL/HDL (0.69) were observed in T6 (1.5\% native strains). The birds fed the native probiotic strains at $150 \mathrm{~g} /$ ton (T6) had the highest MCHC compared to the other treatments, and there was no statistically significant difference between the commercial and native probiotics. The highest and lowest white blood cell counts was observed in native probiotic strains (200 g/ton) and control treatment, respectively, and difference between the CP1 and CP2 with native probiotics was not significant. These results are consistent with those a previous study that showed that the dietary addition of a probiotic did not affect the blood constituents, including hemoglobin concentrations, of ducklings (Djouvinov et al., 2005). Thongsong \& Chavananikul (2008) demonstrated that probiotics significantly increased red blood cell counts, mean hemoglobin concentration, and mean corpuscular hemoglobin concentration of broilers. The white blood cell counts obtained in the present study are in agreement with the findings of Zare et al. (2007) and Fathi (2013), who obtained significantly higher WBC counts in broilers fed probiotics than in those fed a control diet. The manipulation of intestinal microbiota via the utilization of probiotics influences the development of the immune response. The mechanisms that mediate the effects of probiotics on the immune system are not known. However, it was shown that probiotics stimulate several subsets of immune system cells to produce cytokines, which in turn play an important role in the regulation of the immune response (Kabir et al., 2009). Haller et al. (2000) observed that gut microflora imbalance activated the intestinal mucosal immune system, causing an inflammatory reaction in the gut. The results of the present study suggest gut microflora imbalance and its effects on immune stimulation may increase the number of white blood cells. In the present study, the quails fed the diets containing probiotics has WBC compared with the control group. This could be due to their increased serum globulin level. Globulin serves as precursors of immunoglobulins (antibodies). The immune system of birds is composed of various cells and soluble elements (proteins) that need work together to create a protective immune response (Okuneye et al., 2016).

\section{Effect of probiotics on gut microbial population}

As is shown in Table 7, all the probiotics fed in this study influenced $(p<0.05)$ both Lactobacillus bacteria and $E$. coli populations in the cecal and small intestine content samples. The largest Lactobacillus bacterial population was observed in the cecal and small intestine contents of T6 birds (fed $150 \mathrm{~g} / \mathrm{ton}$ native probiotics). Interestingly, the lowest $E$. coli populations were observed in the treatments containing different concentrations of the native probiotics $(50,150$ and $200 \mathrm{~g} / \mathrm{ton})$, followed by T5 and commercial probiotics (CP1 and CP2). These results are in accordance with those of Kizerwetter-Swida \& Binek (2009) who indicated that the Lactobacillus salivarius decreased the number of Clostridium perfringens and Salmonella Enteritidis in the group of chickens treated with Lactobacillus. Yu et al. (2007) evaluated the effects of probiotic Lactobacillus reuteri strain Pg4 on the performance and intestinal characteristics of broilers, and reported that the Lactobacillus populations in the ileum, crop, and cecum of the broilers fed probiotics were higher than those in the control group. Other studies have also shown the potential of probiotics to populate the gut microflora of broiler chickens with beneficial bacteria and to supress the growth potentially pathogenic bacteria (Vicente et al., 2008).

Table 7 - Effects of commercial and native probiotics on viable cell counts of microflora in the cecal and small intestine contents of Japanese quails

\begin{tabular}{lcc}
\hline & \multicolumn{2}{c}{ Counts } \\
\hline Treatment & Lactobacillus spp. & E. coli \\
\hline Control $\left(\mathrm{T}_{1}\right)$ & $2.14^{\mathrm{c}} \pm 0.495$ & $1.36^{\mathrm{a}} \pm 0.039$ \\
CP1 $\left(\mathrm{T}_{2}\right)$ & $5.42^{\mathrm{b}} \pm 0.428$ & $1.28^{\mathrm{ab}} \pm 0.046$ \\
CP2 $\left(\mathrm{T}_{3}\right)$ & $7.54^{\mathrm{a}} \pm 0.666$ & $1.30^{\mathrm{ab}} \pm 0.039$ \\
NP 50g/ton $\left(\mathrm{T}_{4}\right)$ & $7.83^{\mathrm{a}} \pm 0.789$ & $1.14^{\mathrm{b}} \pm 0.058$ \\
NP 100g/ton $\left(\mathrm{T}_{5}\right)$ & $5.26^{\mathrm{b}} \pm 0.400$ & $1.27^{\mathrm{ab}} \pm 0.050$ \\
NP 150g/ton $\left(\mathrm{T}_{6}\right)$ & $8.35^{\mathrm{a}} \pm 0.386$ & $1.15^{\mathrm{b}} \pm 0.066$ \\
NP 200g/ton $\left(\mathrm{T}_{7}\right)$ & $3.99^{\mathrm{b}} \pm 0.496$ & $1.19^{\mathrm{b}} \pm 0.045$ \\
p-Value & 0.0001 & 0.0355 \\
\hline
\end{tabular}

Values are expressed as means \pm standard error of the mean. ${ }^{A-d}$ Values followed by different letters on the same row indicate significant differences $(p<0.05)$. CP = commercial probiotic, NP = native probiotic.

\section{CONCLUSION}

It is concluded that the supplementation of the combination of four native Lactobacillus strains at a concentration of $150 \mathrm{~g} /$ ton feed effectively enhanced the growth performance (BWG and FCR) and blood biochemical parameters of Japanese quails during the starter, finisher, and overall rearing periods. The results show that the mixture of four Lactobacillus strains has a probiotic potential in Japanese quails. 


\section{ACKNOWLEDGEMENTS}

This article is a part of Ph.D. thesis in Animal Science, Islamic Azad University, Shabestar Branch and part of a project of the Agriculture Biotechnology Research Institute of Iran (ABRII). Thesis supervisors: Dr. Y. Ebrahimnezhad and Dr. G. R. Salehi Jouzani. The authors would like to thank all staff of Islamic Azad University, Shabestar Branch, and ABR/l for the technical support.

\section{REFERENCES}

Aazami N, Salehi Jouzani G, Khodaei Z, Meimandipour A, Safari M, Goudarzvand M. Characterization of some potentially probiotic Lactobacillus strains isolated from Iranian native chickens. The Journal of General and Applied Microbiology 2014;60(6):215-221.

Abd-El-Rahman AH, Kamel H, Ahmed WM, Mogoda OS, Mohamed AH. Effect of Bactocell $\circledast$ and revitilyte-plus as probiotic food supplements on the growth performance, hematological, biochemical parameters and humoral immune response of broiler chickens. World Applied Sciences Journal 2012;18(3):305-316.

Al-Kassie G, Al-Jumaa Y, Jameel Y. Effect of probiotic (Aspergillus niger) and prebiotic (Taraxacum officinale) on blood picture and biochemical properties of broiler chicks. International Journal of Poultry Science 2008;7(12):1182-1184.

Alkhalf A, Alhaj M, Al-Homidan I. Influence of probiotic supplementation on blood parameters and growth performance in broiler chickens. Saudi Journal of Biological Sciences 2010;17(3):219-225.

Amerah A, Quiles A, Medel P, Sánchez J, Lehtinen M, Gracia M. Effect of pelleting temperature and probiotic supplementation on growth performance and immune function of broilers fed maize/soy-based diets. Animal Feed Science and Technology 2013;180(1):55-63.

Arslan C. Effect of dietary probiotic supplementation on growth performance in the rock partridge (Alectoris graeca). Turkish Journal of Veterinary and Animal Sciences 2004;28 (5):887-891.

Arslan C, Saatci M. Effects of probiotic administration either as feed additive or by drinking water on performance and blood parameters in Japanese quail. Archiv fur Geflugelkunde 2004;160-163.

Ashayerizadeh O, Dastar B, Shargh MS, Ashayerizadeh A, Mamooee M. Influence of antibiotic, prebiotic and probiotic supplementation to diets on carcass characteristics, hematological indices and internal organ size of young broiler chickens. Journal of Animal and Veterinary Advances 2009;8(9):1772-1776.

Awad W, Ghareeb K, Abdel-Raheem S, Böhm J. Effects of dietary inclusion of probiotic and synbiotic on growth performance, organ weights, and intestinal histomorphology of broiler chickens. Poultry Science 2009;88(1):49-56.

Babazadeh D, Vahdatpour T, Nikpiran H, Jafargholipour M, Vahdatpour S. Effects of probiotic, prebiotic and synbiotic intake on blood enzymes and performance of Japanese quails (Coturnix japonica). Indian Journal of Animal Sciences 2011;81(8):870.

Bitterncourt LC, Silva CCD, Garcia PDSR, Donato DCZ, Albuquerque RD, Araújo LF. Influence of a probiotic on broiler performance. Revista Brasileira de Zootecnia 2011;40(12):2739-2743.

Cakir S, Midilli M, Erol H, Simsek N, Cinar M, Altintas A, et al. Use of combined probiotic-prebiotic, organic acid and avilamycin in diets of
Japanese quails. Revue de Médecine Vétérinaire 2008:159(11):565569.

Cean A, Stef L, Simiz E, Julean C, Dumitrescu G, Vasile A, et al. Effect of human isolated probiotic bacteria on preventing Campylobacter jejuni colonization of poultry. Food Borne Pathogens and Disease 2015;12(2):122-130.

Cengiz Ö, Köksal BH, Tatı O, Sevim Ö, Ahsan U, Üner AG, et al. Effect of dietary probiotic and high stocking density on the performance, carcass yield, gut microflora, and stress indicators of broilers. Poultry Science 2015;94(10):2395-2403.

Cetin N, Güçlü B, Cetin E. The effects of probiotic and mannanoligosaccharide on some haematological and immunological parameters in turkeys. Journal of Veterinary Medicine Series 2005;52 (6):263-267.

Chimote M, Barmase B, Raut A, Dhok A, Kuralkar S. Effect of supplementation of probiotic and enzymes on performance of Japanese quails. Veterinary World 2009;2(6):219-220.

Corrêa G, Gomes A, Corrêa A, Salles A, Mattos E. Efeito de antibiótico e probióticos sobre o desempenho e rendimento de carcaça de frangos de corte. Arquivo Brasileiro de Medicina Veterinária e Zootecnia 2003;55 (4) 467-473.

Dibaji SM, Seidavi A, Asadpour L. Effect of dietary inclusion of the synbiotic Biomin IMBO on broilers' some blood metabolites, research opinions. Animal \& Veterinary Sciences 2012;2:10-13.

Djouvinov D, Boicheva S, Simeonova T, Vlaikova T. Effect of feeding lactina probiotic on performance, some blood parameters and caecal microflora of mule ducklings. Trakia Journal of Sciences 2005;3(2):2228.

Eizaguirre I, Urkia NG, Asensio A, Zubillaga I, Zubillaga P, Vidales C, et al Probiotic supplementation reduces the risk of bacterial translocation in experimental short bowel syndrome. Journal of Pediatric Surgery 2002;37(5):699-702.

El-Faham A, Ali NG, El-Maaty HM. Effect of using some natural feed additives to substitute antibiotic growth promoters on performance and blood parameters of broilers. Egypt Poultry Science 2014;34(111):735-750.

Ergün A, Yalcin S, Sacakli P. The usage of probiotic and zinc bacitracin in broiler rations. Ankara Üniversitesi Veteriner Fakültesi Dergisi 2000;47(3):271-280.

Fathi M. Effects of Lactobacillus cultures as probiotic on blood parameters, plasma enzymes activities and mortality in broiler chicken. Research Journal of Animal Science 2013;7:78-81.

Fuller R. Probiotics in man and animals:A review. Journal of Applied Bacteriology 1989;66:365-378.

Gunal M, Yayli G, Kaya O, Karahan N, Sulak O. The effects of antibiotic growth promoter, probiotic or organic acid supplementation on performance, intestinal microflora and tissue of broilers. International Journal of Poultry Science 2006;5(2):149-155.

Haller D, Bode C, Hammes WP, Pfeifer AMA, Schiffrin EJ, Blum S. Nonpathogenic bacteria elicit a differential cytokine response by intestinal epithelial cell/leucocyte co-cultures. Gut 2000;47:79-87.

Hashemi SR, Zulkifli I, Davoodi H, Zunita Z, Ebrahimi M. Growth performance, intestinal microflora, plasma fatty acid profile in broiler chickens fed herbal plant (Euphorbia hirta) and mix of acidifiers. Animal Feed Science and Technology 2012;178 (3):167-74.

Hippenstiel F, Abdel-Wareth A, Kehraus S, Südekum K. Effects of selected herbs and essential oils, and their active components on feed intake and performance of broilers-a review. European Poultry Science 2011;75(4):226-234. 
Siadati SA, Ebrahimnezhad Y, Salehi Jouzani G, Shayegh J

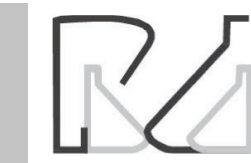

Evaluation of Probiotic Potential of Some Native

Lactobacillus Strains on the Growth Performance and Serum Biochemical Parameters of Japanese Quails (Coturnix Coturnix Japonica) during Rearing Period
Hosseini SA, Meimandipour A, Alami F, Mahdavi A, Mohiti-Asli M Lotfollahian $\mathrm{H}$, et al. Effects of ground thyme and probiotic supplements in diets on broiler performance, blood biochemistry and immunological response to sheep red blood cells. Italian Journal of Animal Science 2013;12(1):e 19

Kabir SL, Rahman MM, Rahman M, Rahman M, Ahmed S. The dynamics of probiotics on growth performance and immune response in broilers. International Journal of Poultry Science 2004;3(5):361-364.

Kabir SM. The role of probiotics in the poultry industry. International Journal of Molecular Sciences 2009;10(8):3531-3546

Kalavathy R, Abdullah N, Jalaludin S, Ho Y. Effects of Lactobacillus cultures on growth performance, abdominal fat deposition, serum lipids and weight of organs of broiler chickens. British Poultry Science 2003;44(1):139-144.

Kasmani FB, Torshizi MK, Allameh A, Shariatmadari F. A novel aflatoxinbinding Bacillus probiotic:Performance, serum biochemistry, and immunological parameters in Japanese quail. Poultry Science 2012; 91(8):1846-1853.

Kermanshahi H, Daneshmand A, Emami NK, Tabari DG, Doosti M, Javadmanesh A, et al. Effect of in ovo injection of threonine on Mucin2 gene expression and digestive enzyme activity in Japanese quail (Coturnix japonica). Research in Veterinary Science 2015;100:257-262.

Khaksar V, Krimpen MV, Hashemipour H, Pilevar M. Effects of thyme essential oil on performance, some blood parameters and ileal microflora of Japanese quail. Journal of Poultry Science 2012;49(2):106-110.

Khaksefidi A, Ghoorchi T. Effect of probiotic on performance and immunocompetence in broiler chicks. Journal of Poultry Science 2006;43(3):296-300

Kheiri F, Rostami M, Hajiabadi S. The effects of Protexin probiotic and chicoridin supplementation on performance and some hematological parameters in Japanese quail (Coturnix japonica). Agricultural Advances 2015;4(10):115-121

Kizerwetter-Swida M, Binek M. Protective effect of potentially probiotic Lactobacillus strain on infection with pathogenic bacteria in chickens. Polish Journal of Veterinary Science 2009;12:15-20.

Mountzouris K, Tsirtsikos P, Kalamara E, Nitsch S, Schatzmayr G. Evaluation of the efficacy of a probiotic containing Lactobacillus, Bifidobacterium, Enterococcus, and Pediococcus strains in promoting broiler performance and modulating cecal microflora composition and metabolic activities. Poultry Science 2007;86(2):309-317.

Newaj-Fyzul A, Adesiyun A, Mutani A, Ramsubhag A, Brunt J, Austin B. Bacillus subtilis $A B 1$ controls Aeromonas infection in rainbow trout (Oncorhynchus mykiss, Walbaum). Journal of Applied Microbiology 2007;103(5):1699-1706

NRC - National Research Council. Nutrient requirements of poultry. Washington: National Academy Press; 1994.

Okuneye OJ, Adeoye AT, Oloso NO, Adekunle OF, Fasanmi OG. Performance and physiological responses of Salmonella enteritidis challenged broilers fed diets containing antibiotic, probiotic and aromabiotic. Journal of Dairy, Veterinary \& Animal Research 2016;3(3):1-6.

Panda AK, Ramarao SV, Raju MV, Sharma SR. Dietary supplementation of probiotic Lactobacillus sporogenes on performance and serum biochemico-lipid profile of broiler chickens. Journal of Poultry Science 2006;43(3):235-240

Pelicano ERL, De Souza P, De Souza H, Leonel F, Zeola N, Boiago M. Productive traits of broiler chickens fed diets containing different growth promoters. Revista Brasileira de Ciência Avícola 2004;6(3):177182.
Ramarao S, Reddy M, Raju M, Panda A. Growth, nutrient utilization and immunecompetence in broiler chicken fed probiotic, gut acidifier and antibacterial compounds. Indian Journal of Poultry Science 2004;39(2):125-130.

Ramirez-Chavarin M, Wacher C, Eslava-Campos C, Perez-Chabela M. Probiotic potential of thermotolerant lactic acid bacteria strains isolated from cooked meat products. International Food Research Journal 2013;20(2):991-1000

Sahin T, Kaya I, Unal Y, Elmali DA. Dietary supplementation of probiotic and prebiotic combination (Combiotics) on performance, carcass quality and blood parameters in growing quail. Journal of Animal and Veterinary Advances 2008;7(11):1370-1373.

Salim H, Abd-Allah O, Fararh K. Effect of feeding probiotic on hematological, biochemical properties and immune response in broiler. Benha Veterinary Medical Journal 2011;22(2):35-43

SAS Institute. SAS user's guide. version 9.1. Cary: SAS institute; 2003.

Scholz-Ahrens KE, Ade P, Marten B, Weber P, Timm W, Acil Y, et al. Prebiotics, probiotics, and synbiotics affect mineral absorption, bone mineral content, and bone structure. Journal of Nutrition 2007;137(3):838S-846S.

Sharifi MR, Shams M, Dastar B, Hosseini S. The effect of dietary protein and synbiotic on performance parameters, blood characteristics and carcass yields of Japanese quail (Coturnix japonica). Italian Journal of Animal Science $2011 ; 10(1): 4$

Siriken B, Bayram I, Onol AG. Effects of probiotics:alone and in a mixture of Biosacc $₫$ plus Zinc Bacitracin on the caecal microflora of Japanese quail. Research in Veterinary Science 2003;75(1):9-14.

Smug L, Salminen S, Sanders M, Ebner S. Yoghurt and probiotic bacteria in dietary guidelines of the member states of the European Union. Beneficial Microbes 2014;5(1):61-66.

Thongsong SK-TB, Chavananikul V. Blood haematological-cholesterol profile and antibody titer response of broilers with added probiotic containing both bacteria and yeast or an antibiotic in drinking water. Thai Journal of Veterinary Medicine 2008;38(4):45-56

Tonekabon I. Studies on Bacillus subtilis, as potential probiotics, on the biochemical parameters of rainbow trout, Oncorhynchus mykiss (Walbaum) to challenge infections. Advanced Studies in Biology 2013;5(1):37-50.

Vandeplas S, Dauphin RD, Thiry C, Beckers Y, Welling GW, ThonartP, et al. Efficiency of a Lactobacillus plantarum-xylanase combination on growth performances, microflora populations, and nutrient digestibilities of broilers infected with Salmonella Typhimurium. Poultry Science 2009;88(8):1643-1654

Vicente JL, Torres-Rodriguez A, Higgins SE, Pixley C, Tellez G, Donoghue AM, Hargis BM. Effect of a selected Lactobacillus spp.-based probiotic on Salmonella enterica serovar Enteritidis-infected broiler chicks. Avian Diseases 2008;52(1):143-146.

Yalçın S, Önol A, Şehu A, Onbaşılar í. Bıldırcın besisinde enzim, probiyotik ve antibiyotik kullanılması. Veteriner Fakultesi Dergisi 2000;47:351-360.

Yu B, Liu J, Chiou M, Hsu Y, Chiou P. The effects of probiotic Lactobacillus reuteri Pg4 strain on intestinal characteristics and performance in broilers. Asian Australasian Journal of Animal Sciences 2007;20(8):1243-1251.

Zare SA, Abd EM, Kamyab A, Nikkhah A. Effect of different levels of bacterial probiotic on broilers performance and some of blood factors. Journal of Agricultural Science and Natural Resources 2007;14 (4):162170 
